\title{
SELEKSI ISOLAT BAKTERI ASAM LAKTAT ASAL TEMPE DAN TAPE SEBAGAI KANDIDAT PROBIOTIK
}

\author{
[Selection of Lactic Acid Bacteria Isolated from Tempe and Tape \\ as Probiotic Candidates]
}

\author{
Raini Panjaitan ${ }^{1)}$, Lilis Nuraida ${ }^{2)_{\star}}$, dan Ratih Dewanti-Hariyadi ${ }^{2)}$ \\ 1) Program Studi IImu Pangan, Sekolah Pascasarjana, Institut Pertanian Bogor, Bogor \\ ${ }^{2)}$ Departemen Ilmu dan Teknologi Pangan, Fakultas Teknologi Pertanian, Institut Pertanian Bogor, Bogor
}

Diterima 26 Januari 2018 / Disetujui 24 Oktober 2018

\begin{abstract}
Lactic acid bacteria ( $L A B$ ) have been isolated from Indonesian fermented foods such as tempe and tape. Some lactic acid bacteria are known to have health benefits and as probiotics. The objective of this study was to evaluate the probiotic potential of lactic acid bacteria isolated from tempe and tape. $L A B$ isolated from tape were evaluated for their tolerance towards low $\mathrm{pH}(\mathrm{pH} 2.0)$ and $0.5 \%$ bile salt. $L A B$ isolated from tape and tempe resistant to low $\mathrm{pH}$ and bile salt were then evaluated for their antimicrobial activities against pathogenic bacteria (E. coli ATCC 25922, S. typhimurium ATCC 14028, L. monocytogenes ATCC 7644, S. aureus ATCC 25923 and B. cereus ATCC 11778). The isolates were also tested for their adherence properties, consisting of hidrophobicity test using microbial adhesion to solvents (MATS) assay, autoaggregation as well as coaggregation between $L A B$ and pathogens. The results of this study indicated that three isolates from tape (L. fermentum 1 BK2-5, L. fermentum 2 BK2-7, P. acidilactici NG64) showed good tolerance to $\mathrm{pH} 2.0$ and $0.5 \%$ bile salt. L. fermentum $\mathrm{S} 21209$ isolated from tempe showed the strongest antimicrobial activity against the five pathogens tested. Based on the adhesion to xylene, $L$. fermentum 1 BK 2-5 was categorized as strong hydrophobic, followed by L. fermentum S21209 and L. fermentum TS4-5. Meanwhile, L. fermentum TS 4-5, L. fermentum S21209, L. fermentum 1 BK 2-5 and P. pentose-ceus 1 W2SR04 have the highest autoaggregation ability. L. fermentum S21209 also had the highestco-aggregation ability to the five pathogenic bacteria tested. The ability of $L A B$ to coaggregate with all pathogens tested correlated with their strong antimicrobial properties. Based on the resistance toward low $\mathrm{pH}$ and bile salt, antimicrobial activity and adherence properties, L. fermentum $\$ 21209$ from tempe and L. fermentum 1 BK 2-5 from tape are the most potential as probiotic candidates.
\end{abstract}

Keywords: aggregation, antimicrobial, probiotic, tape, tempe

\section{ABSTRAK}

Bakteri asam laktat (BAL) telah diisolasi dari produk pangan fermentasi In donesia seperti tempe dan tape. Beberapa bakteri asam laktat telah diketahui memiliki manfaat kesehatan dan dikenal sebagai probiotik. Tujuan dari penelitian ini adalah untuk mengevaluasi potensi probiotik BAL asal tempe dan tape. Isolat-isolat $\mathrm{BAL}$ asal tape diuji toleransinya pada $\mathrm{pH}$ rendah $(\mathrm{pH} 2,0)$ dan garam empedu $0,5 \%$. Isolat $\mathrm{BAL}$ asal tempe dan tape yang telah diketahui ketahanannya terhadap $\mathrm{pH}$ dan garam empedu selanjutnya diuji aktivitas antimikroba terhadap bakteri patogen ( $E$. coli ATCC 25922, S.typhimurium ATCC 14028, L. monocytogenes ATCC 7644, S. aureus ATCC 25923 dan B.cereus ATCC 11778). Isolat BAL juga diuji sifat penempelannya, yang terdiri dari uji hidrofobisitas menggunakan metode microbial adhesion to solvents (MATS), autoagregasi dan koagregasi antara BAL dan patogen. Hasil penelitian ini menunjukkan bahwa tiga isolat BAL asal tape ( $L$. fermentum 1 BK2-5, L. fermentum 2 BK2-7, $P$. acidilactici NG6-4) menunjukkan toleransi yang baik terhadap $\mathrm{pH}$ 2,0 dan 0,5\% garam empedu. L. fermentum S21209 asal tempe memiliki aktivitas antimikroba paling kuat terhadap kelima patogen uji. Berdasarkan afinitas terhadap xilena, L. fermentum 1 BK2-5 merupakan isolat BAL yang memiliki hidrofobisitas yang paling kuat, diikuti oleh L. fermentum S21209 dan L. fermentum TS4-5. L. fermentum TS4-5, L. fermentum S21209, L. fermentum 1 BK2-5 dan P. pentosaceus 1 W2SR04 memiliki kemampuan autoagregasi tertinggi. Isolat L. fermentum S21209 juga memiliki kemampuan koagregasi tertinggi dengan kelima bakteri patogen. Kemampuan koagregasi BAL dengan semua patogen yang diuji berkorelasi dengan sifat antimikrobanya yang kuat. Berdasarkan ketahanan terhadap $\mathrm{pH}$ rendah dan garam empedu, sifat antimikroba dan sifat penempelannya, L. fermentum S21209 dari tempe dan L. fermentum 1 BK2-5 dari tape merupakan kandidat probiotik yang paling potensial.

Kata kunci: agregasi, antimikroba, probiotik, tape, tempe

*Penulis Korespondensi:

E-mail: Inuraida@gmail.com 


\section{PENDAHULUAN}

Bakteri asam laktat (BAL) adalah kelompok bakteri yang memproduksi asam laktat sebagai produk metabolit utama dari fermentasi karbohidrat. BAL dapat diperoleh dari pangan hasil fermentasi, seperti tempe dan tape. Tempe merupakan makanan fermentasi tradisional Indonesia dari bahan baku kedelai dan dikenal sebagai hasil fermentasi kapang. Fermentasi tempe melibatkan komunitas mikroba yang kompleks, yang berkembang sejak awal proses perendaman dan mencapai jumlah maksimum pada tempe segar. Beberapa penelitian menunjukkan bahwa bakteri asam laktat (BAL) dan kapang merupakan mikroba yang dominan pada tempe dalam jumlah tinggi $\left(10^{7}-10^{8} \mathrm{CFU} / \mathrm{g}\right.$ ) (Efriwati et al., 2013; Nurdini et al., 2015). Tape merupakan makanan fermentasi tradisional dengan rasa manis, asam dan alkohol, yang terbuat dari bahan baku singkong, ketan dan bahan-bahan lain dengan menggunakan ragi sebagai kultur starter yang berisi kapang, khamir dan bakteri (Nuraida dan Owens, 2014). BAL yang ditemukan pada tape ketan dan tape singkong terdiri atas tiga jenis yaitu kokus homofermentatif, batang homofermentatif, dan batang heterofermentatif (Ratihwulan, 2016).

Menurut Nuraida dan Owens (2014), BAL yang terdapat pada tape diantaranya adalah Wisella spp., Lactobacillus spp., Pediococcus pentosaceus, dan Enterococcus spp. yang terdeteksi setelah 24 jam fermentasi dan jumlahnya menurun seiring waktu fermentasi. Beberapa bakteri asam laktat telah diketahui memiliki manfaat kesehatan dan dikenal sebagai probiotik. Probiotik didefinisikan sebagai mikroorganisme hidup yang memberikan manfaat kesehatan bagi inangnya apabila dikonsumsi dalam jumlah yang cukup (FAO/WHO, 2002). Beberapa kriteria harus dipenuhi oleh suatu mikroorganisme untuk dapat dikategorikan sebagai probiotik, yaitu memiliki: ketahanan terhadap asam lambung dan garam empedu, kemampuan menghambat bakteri patogen, kemampuan menempel pada sel epitel usus dan kemampuan menghambat penempelan bakteri patogen pada sel epitel. Probiotik yang telah banyak dikenal saat ini umumnya merupakan kelompok BAL, terutama dari genus Lactobacillus dan Bifidobacterium. Bakteri asam laktat yang berpotensi sebagai probiotik dapat diperoleh dari produk-produk fermentasi (Chávarri et al., 2012; Nuraida, 2015). Touw (2014) telah mengidentifikasi isolat BAL asal tempe sebagai Enterococcus faecium, Lactobacillus plantarum, Pediococcus acidilactici, Weisela confusa, Pediococcus pentosaceus, dan Lactobacillus fermentum. Ketahanan BAL asal tempe terhadap garam empedu dan $\mathrm{pH}$ rendah bervariasi, dengan isolat yang paling mampu bertahan pada $\mathrm{pH}$ rendah dan garam empedu adalah L. fermentum sehingga isolat $\mathrm{BAL}$ ini berpotensi sebagai probiotik (Touw, 2014).
Probiotik telah banyak digunakan untuk pencegahan maupun pengobatan penyakit seperti penanggulangan diare (Samaržija et al., 2009; Blaabjerg et al., 2017), menstimulasi sistem kekebalan (immune) tubuh (Patrick, 2012; Ganjbakhsh dan Rezaee, 2017), menurunkan kadar kolesterol (Nuraida et al., 2011; Pan et al., 2011; Choi dan Chang, 2015), mengatasi intoleransi laktosa (Kinová et al., 2008; Vonk et al., 2012), pencegahan kanker kolon dan usus (Kumar et al., 2015; Sivieri et al., 2013). Beberapa penelitian menunjukkan isolat $\mathrm{BAL}$ indigenus dari makanan fermentasi Indonesia terbukti mampu mereduksi kolesterol (Pato et al., 2004; Antara et al., 2009) dan mencegah diare (Arief et al., 2010; Emmawati, 2015). Penelitian ini mengevaluasi potensi probiotik BAL asal tempe dan tape dengan melakukan pengujian sesuai dengan persyaratan dasar probiotik. Isolat BAL yang berasal dari tempe telah diuji ketahanannya terhadap $\mathrm{pH}$ rendah dan garam empedu (Touw, 2014) sehingga pada penelitian ini BAL asal tempe diuji sifat antimikroba, hidrofobisitas dan agregasinya. Kemampuan agregasi suatu bakteri berkorelasi dengan kemampuan menempel pada saluran pencernaan (Janković et al., 2012; GarciaCayuela et al., 2014). Evaluasi in vitro terhadap sifat hidrofobisitas BAL, kemampuan BAL melakukan autoagregasi merupakan seleksi awal untuk mengetahui kemampuan BAL untuk menempel pada saluran pencernaan. Selain itu kemampuan BAL dan melakukan koagregasi dengan bakteri patogen merupakan sifat yang penting untuk menghambat kolonisasi bakteri patogen.

\section{BAHAN DAN METODE}

\section{Bahan}

Kultur BAL yang digunakan adalah BAL asal tempe, tape singkong dan tape ketan serta kultur bakteri patogen (Escherichia coli ATCC 25922, Salmonella typhimurium ATCC 14028, Listeria monocytogenes ATCC 7644, Staphylococcus aureus ATCC 25923, dan Bacillus cereus ATCC 11778) diperoleh dari SEAFAST Center IPB.

\section{Uji ketahanan isolat bakteri asam laktat asal tape terhadap $\mathrm{pH} 2,0$}

Pengujian ini berdasarkan metode Nuraida et al. (2011) dengan menggunakan medium deMan, Rogosa and Sharpe Broth (MRSB) (Oxoid ${ }^{\mathrm{TM}}$ ) pada $\mathrm{pH} 2,0$. Kultur BAL disegarkan dalam medium MRSB selama 24 jam, diinokulasikan sebanyak 0,1 $\mathrm{mL}$ ke dalam $10 \mathrm{~mL}$ medium MRSB sebagai kontrol dan MRSB ber $\mathrm{pH}$ 2,0 diatur dengan menambahkan $\mathrm{HCl} 37 \%$ (Merck $^{\text {TM }}$ ). Kemudian diinkubasi pada suhu $37^{\circ} \mathrm{C}$ selama 5 jam. Setelah diinkubasi sel dihitung pada medium deMan, Rogosa and Sharpe Agar (MRSA) (Oxoid ${ }^{\mathrm{TM}}$ ) dengan metode tuang. Ketahan- 
an terhadap $\mathrm{pH}$ 2,0 dihitung berdasarkan selisih unit log jumlah koloni yang tumbuh pada kontrol dengan perlakuan. Semakin kecil selisihnya, maka semakin tahan kultur BAL tersebut terhadap $\mathrm{pH} 2,0$.

\section{Uji ketahanan isolat bakteri asam laktat asal tape terhadap garam empedu}

Pengujian ini dilakukan berdasarkan Park et al. (2006) yang dimodifikasi oleh Nuraida et al. (2011) dengan menggunakan medium MRSB yang berisi garam Oxgall (Difco ${ }^{\mathrm{TM}}$ ) $0,5 \%$. Kultur BAL disegarkan dalam medium MRSB selama 24 jam, diinokulasikan sebanyak $0,1 \mathrm{~mL}$ ke dalam $10 \mathrm{~mL}$ medium MRSB sebagai kontrol dan $10 \mathrm{~mL}$ MRSB yang mengandung garam Oxgall $0,5 \%$, kemudian diinkubasi pada suhu $37^{\circ} \mathrm{C}$ selama 5 jam. Setelah diinkubasi sel dihitung pada MRSA dengan metode tuang. Ketahanan isolat BAL terhadap garam empedu dihitung berdasarkan selisih unit log jumlah koloni yang tumbuh pada kontrol dengan perlakuan. Semakin kecil selisihnya, maka semakin tahan kultur BAL tersebut terhadap garam empedu.

\section{Identifikasi isolat BAL asal tape dengan KIT API $50 \mathrm{CHL}$}

Isolat BAL asal tape ditumbuhkan pada medium MRSA dan diinkubasi pada suhu $30^{\circ} \mathrm{C}$ selama 24 jam. Kemudian kultur yang telah tumbuh disuspensikan ke dalam medium API $50 \mathrm{CHL}$ (BioMeriux, France) dan divortex. Sekitar $8 \mathrm{~mL}$ air dialirkan ke dalam baki inkubasi, kemudian gallery diletakkan pada baki yang berisi air steril sebagai pelembab. Media $50 \mathrm{CHL}$ yang telah diinokulasi dengan kultur BAL, kemudian dipipet ke masing-masing cupule dan ditutup dengan parafin cair steril untuk menciptakan suasana anaerob. Selanjutnya, baki diinkubasi pada suhu $30^{\circ} \mathrm{C}$ selama 48 jam. Hasil dari reaksi biokimia tersebut diamati secara visual berdasarkan petunjuk kit API $50 \mathrm{CHL}$ dan dianalisis menggunakan software APlweb ${ }^{\text {TM }}$ API 50 CHLV5.1 (www.api web.biomerieux.com).

\section{Uji aktivitas antimikroba isolat BAL asal tempe dan tape terhadap bakteri patogen}

Pengujian aktivitas antimikroba BAL terhadap patogen dilakukan dengan metode sumur (Pan et al., 2009). Kultur bakteri patogen ditumbuhkan dalam Tryptone Soya Broth (TSB) (Oxoid ${ }^{\text {TM }}$ ) dan kultur BAL ditumbuhkan dalam MRSB selama 18 jam. Sejumlah $25 \mu \mathrm{L}$ kultur dari setiap bakteri patogen dituangkan pada $25 \mathrm{~mL}$ Tryptone Soya Agar (TSA) $\left(\right.$ Oxoid $\left.{ }^{\mathrm{TM}}\right)$, lalu dituangkan pada cawan dan dibiarkan memadat. Sumur berukuran $6 \mathrm{~mm}$ dibuat pada agar dan $50 \mu \mathrm{L}$ kultur BAL yang diuji diinokulasikan pa-da sumur. Setelah inkubasi pada suhu $35^{\circ} \mathrm{C}$ selama 16 jam, diameter zona penghambatan diukur dari 3 sisi berbeda. Diameter penghambatan adalah hasil pengukuran dikurangi dengan diameter sumur.

\section{Uji hidrofobisitas bakteri asam laktat asal tempe dan tape}

Penentuan hidrofobisitas bakteri dilakukan dengan metode Microbial adhesion to solvents (MATS) (Kos et al., 2003) dengan menggunakan pelarut yang berbeda-beda kepolarannya yaitu xilena (Merck ${ }^{\mathrm{TM}}$ ), etil asetat (Merck ${ }^{\mathrm{TM}}$ ), dan kloroform $\left(\right.$ Merck $\left.^{\mathrm{TM}}\right)$. Adhesi sel bakteri terhadap xilena mencerminkan hidrofobisitas, sedangkan adhesi terhadap kloroform dan etil asetat mencerminkan sifat permukaan sel. Bakteri ditumbuhkan dalam MRSB pada suhu $37^{\circ} \mathrm{C}$ selama $16-18$ jam. Kemudian, sel dipanen dengan cara sentrifugasi (Hermle Z $383 \mathrm{~K}$ ) pada $3500 \mathrm{rpm}$ selama 20 menit. Endapan yang diperoleh dicuci dengan bufer phosphate urea magnesium (PUM). Kemudian, disuspensikan ke dalam bufer PUM sampai mencapai jumlah $10^{8} \mathrm{CFU} / \mathrm{mL}$. Suspensi tersebut kemudian diukur nilai absorbansi awal pada panjang gelombang $600 \mathrm{~nm}\left(\mathrm{~A}_{0}\right)$. Lima mililiter suspensi sel dalam PUM bufer dipindahkam ke dalam tabung yang bersih dan kering dengan dasar bundar kemudian ditambahkan pelarut yang berbeda-beda (xilena, etil asetat, dan kloroform) sebanyak $1 \mathrm{~mL}$ dan dicampur dengan vorteks pada kecepatan tinggi selama 1 menit. Selanjutnya, tabung reaksi didiamkan selama 1 jam pada suhu $37^{\circ} \mathrm{C}$ untuk pemisahan fase. Fase aqueous dipindahkan dengan hati-hati menggunakan pipet steril untuk diukur absorbansinya dengan alat spektrofotometer (Shima$\mathrm{dzu}$ ) pada panjang gelombang $600 \mathrm{~nm}\left(\mathrm{~A}_{1}\right)$.

Penurunan nilai absorbansi pada fase aqueous dinyatakan sebagai nilai adhesi terhadap pelarut (\%) dengan menggunakan persamaan berikut:

$$
\text { Adhesi }(\%)=\left(1-A_{0} / A_{1}\right) \times 100
$$

dimana, $A_{0}=$ nilai absorbansi awal pada $600 \mathrm{~nm} ; A_{1}$ = nilai absorbansi akhir pada $600 \mathrm{~nm}$.

\section{Uji autoagregasi bakteri asam laktat asal tempe dan tape (Kos et al., 2003)}

Isolat BAL ditumbuhkan pada MRSB selama 18 jam pada suhu $37^{\circ} \mathrm{C}$. Sel BAL dipanen dengan sentrifugasi pada 3500 rpm selama 20 menit. Endapan yang diperoleh selanjutnya dicuci dua kali dengan phosphate buffer saline (PBS) dan disuspensikan ke dalam PBS sampai mencapai jumlah $10^{8} \mathrm{CFU} / \mathrm{mL}$. Autoagregasi ditentukan dengan mengukur absorbansi awal (0 jam) dan absorbansi akhir (5 jam) setelah inkubasi pada suhu ruang. Pengukuran absorbansi dilakukan dengan mengambil sebanyak 0,1 $\mathrm{mL}$ suspensi bagian atas dan dimasukkan ke dalam 3,9 mL PBS kemudian diukur absorbansinya dengan alat spektrofotometer pada $600 \mathrm{~nm}$. Persentase autoagregasi dinyatakan sebagai berikut:

$$
\text { Autoagregasi }(\%)=1-\left(A_{t} / A_{0}\right) \times 100
$$


dimana, $A_{t}=$ absorbansi pada waktu $t=5 ; A_{0}=$ absorbansi pada $\mathrm{t}=0$.

Uji koagregasi bakteri asam laktat asal tempe
dan tape (Kos et al., 2003)
Isolat BAL dan lima bakteri patogen ditumbuhkan pada MRSB dan TSB, selama 18 jam pada suhu $37^{\circ} \mathrm{C}$. Sel $B A L$ dan sel patogen dipanen dengan sentrifugasi 3500 rpm selama 20 menit. Endapan yang diperoleh dicuci dua kali dan disuspensikan ke dalam PBS sampai mencapai jumlah $10^{8} \mathrm{CFU} / \mathrm{mL}$. Dua mililiter dari masing-masing suspensi kemudian diambil dan dicampur pada satu tabung. Tabung kontrol berisi $4 \mathrm{~mL}$ masing-masing suspensi bakteri. Koagregasi ditentukan dengan mengukur absorbansi awal (0 jam) dan absorbansi akhir (5 jam) setelah inkubasi pada suhu ruang. Pengukuran absorbansi dilakukan dengan mengambil sebanyak $0,1 \mathrm{~mL}$ sus pensi bagian atas dan dimasukkan ke dalam 3,9 mL PBS kemudian diukur absorbansinya dengan alat spektrofotometer pada $600 \mathrm{~nm}$. Persentase koagregasi dinyatakan sebagai berikut:

$$
\text { Koagregasi } \left.\left.(\%)=\left[\left(A_{x}+A_{y}\right) / 2\right)-A_{x+y}\right)\right] /\left(A_{x}+A_{y}\right) \times 100
$$

dimana, $A_{x}=$ absorbansi suspensi isolat BAL; $A_{y}=$ absorbansi suspensi isolat patogen; $A_{x+y}=$ absorbansi campuran suspensi isolat BAL dan patogen.

\section{Analisis data}

Data hasil percobaan diolah dengan ANOVA menggunakan perangkat lunak SPSS versi 22.0 untuk menentukan perbedaan taraf perlakuan. Hasil berbeda antar taraf perlakuan dilanjutkan dengan uji lanjut Duncan dan nilai signifikan ditentukan berdasarkan taraf nyata $5 \%$.

\section{HASIL DAN PEMBAHASAN}

\section{Ketahanan BAL asal tape terhadap pH 2,0 dan garam empedu}

Hasil pengujian ketahanan BAL asal tape terhadap $\mathrm{pH}$ 2,0 dan garam empedu disajikan pada Gambar 1. Dua isolat BAL asal tape ketan yaitu BK 2-5 dan BK 2-7 menunjukkan toleransi terhadap $\mathrm{pH}$ 2,0 dan garam empedu (Gambar 1a), dan hanya sa$\mathrm{tu}$ isolat BAL asal tape singkong yang memiliki toleransi tinggi terhadap asam dan garam empedu yaitu NG 6-4 (Gambar 1b). BAL yang agak tahan terhadap $\mathrm{pH}$ 2,0 dan garam empedu adalah NG6-3, SH68, dan TS4-5. Kemampuan BAL asal tempe bertahan pada $\mathrm{pH}$ 2,0 dan garam empedu telah diuji oleh Touw (2014). BAL yang paling toleran adalah $L$. fermentum S21209, sedangkan BAL yang memiliki toleransi menengah adalah L. delbrueckii W24802 dan yang toleran terhadap garam empedu adalah $P$. pentosaceus 1 W2SR04, $P$. Pentosaceus 2 W2SR 05, W.confusa S2SR08, dan L. plantarum W22409.

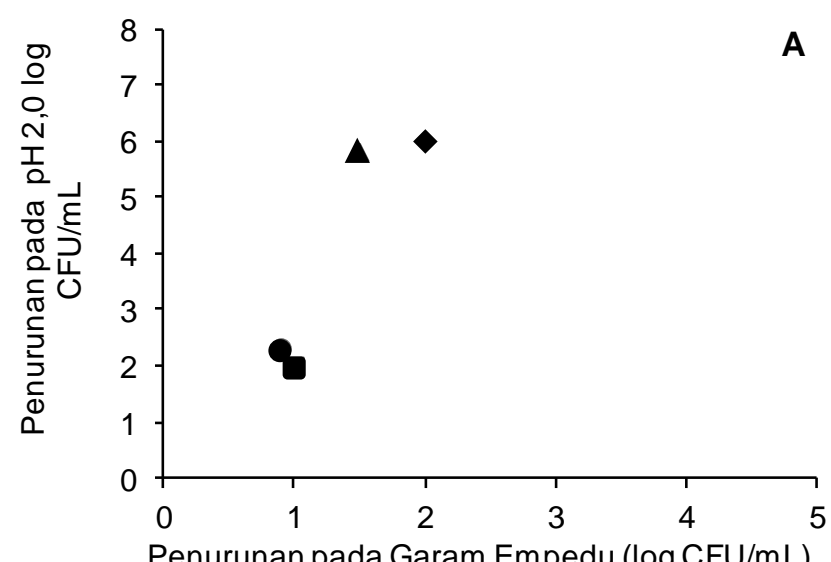

Penurunan pada Garam Empedu (log CFU/mL)

$\Delta$ LK 2-5 B BK2-5 BK2-7 • LK 4-1

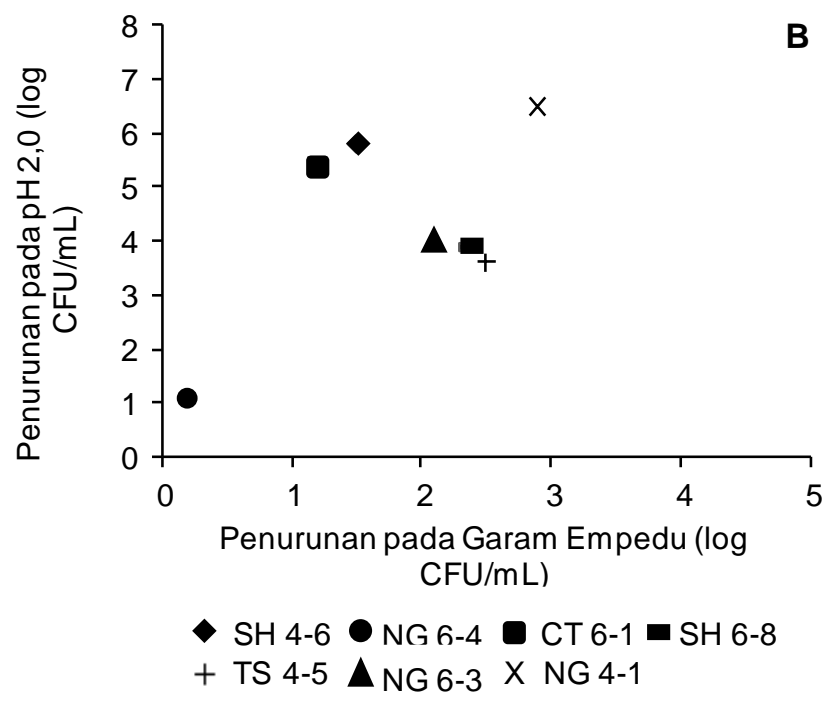

Gambar 1. Penurunan jumlah sel pada $\mathrm{pH} 2,0$ dan garam empedu $0,5 \%$ (A) BAL asal tape ketan dan (B) BAL asal tape singkong

Kemampuan menoleransi asam dan garam empedu ditandai oleh kemampuan bertahan dalam media yang mengandung $0,5 \%$ garam empedu, dengan selisih jumlah dibawah 2 log. Kemampuan toleransi $\mathrm{pH} 2,0$ dan $0,5 \%$ garam empedu merupakan karakteristik yang penting dimiliki oleh bakteri probiotik, sebab hal ini merupakan syarat untuk dapat melewati saluran pencernaan dan sampai di kolon. Menurut Nuraida et al. (2011), kemampuan isolat BAL bertahan pada kondisi asam tergantung pada galur bakteri. Dalam kondisi asam, BAL dapat menjaga sitoplasma lebih rendah keasamannya dari keasaman media, sehingga protein dan enzim dalam sel bekerja dengan optimal. Isolat BAL dapat beradaptasi dalam $\mathrm{pH}$ rendah karena mampu menyeimbangkan $\mathrm{pH}$ sel internal. Penyeimbangan $\mathrm{pH}$ internal dilakukan dengan mengeluarkan proton $\left(\mathrm{H}^{+}\right)$dari dalam sel melalui proses hidrolisis ATP $\left(\mathrm{H}^{+}\right.$-ATPase). Selain itu, BAL juga memiliki histidin dekarboksilase 
dan arginin deaminase yang juga berperan dalam bertahan pada kondisi asam (Pan et al., 2011).

\section{Hasil identifikasi isolat BAL asal tape terpilih dengan Kit API 50 CHL}

Tabel 1 menunjukkan genus bakteri BAL yang terpilih dari tape ketan dan singkong adalah genus Lactobacillus, sedangkan pada tape singkong Lactobacillus dan Pediococcus. Menurut Nuraida dan Owens (2014), BAL yang tumbuh pada tape diantaranya adalah Wisella spp., Lactobacillus spp., Pediococcus pentosaceus, dan Enterococcus spp. Lactobacillus fermentum BK2-5 dan BK2-7 asal tape ketan dan Pediococcus acidilactici NG6-4 asal tape singkong merupakan BAL yang tahan $\mathrm{pH}$ 2,0 dan garam empedu (Gambar 1).

\section{Aktivitas antimikroba BAL asal tempe dan tape terhadap bakteri patogen}

Berdasarkan pengujian sebelumnya, terdapat 12 isolat BAL yang terpilih. $\mathrm{Ke}-12$ isolat BAL tersebut diuji aktivitas antimikroba terhadap lima bakteri uji (Tabel 2). Penghambatan tertinggi terhadap $E$. coli ditunjukkan oleh isolat $L$. plantarum 2 W22409 dan tidak berbeda nyata dengan $L$. fermentum S212 09; penghambatan tertinggi terhadap $S$. typhimurium oleh L. plantarum 2 W22409 yang tidak berbeda dengan L. fermentum S21209; penghambatan tertinggi terhadap $L$. monocytogenes oleh isolat $L$. fermentum S21 209; penghambatan tertinggi terhadap $S$. aureus oleh isolat $P$. pentosaceus 1 W2SR04 yang tidak berbeda dengan L. fermentum S21209; dan penghambatan tertinggi terhadap $B$. cereus oleh isolat $P$. acidilactici NG6-4. Berdasarkan data tersebut, L. fermentum S21209 memiliki sifat antimikroba tertinggi terhadap empat bakteri patogen uji. Isolat ini juga menunjukkan aktivitas penghambatan yang cukup tinggi terhadap $B$. cereus (Tabel 2).

Dari kelima patogen, L. monocytogenes merupakan patogen yang paling sensitif terhadap semua isolat BAL asal tape dan tempe. Penelitian Todorov et al. (2013) menunjukkan dari 65 isolat BAL, terdapat 40 isolat dengan aktivitas antimikroba terhadap $L$. monocytogenes dengan zona penghambatan lebih besar dari $15 \mathrm{~mm}$. Aktivitas antimikroba BAL disebabkan adanya satu atau lebih senyawa antimikroba seperti asam organik (terutama asam laktat dan asetat), hydrogen peroksida dan bakteriosin, tergantung dari spesies dan galurnya (Reis et al., 2012). L. fermentum 1 selain memproduksi asam, kemungkinan menghasilkan senyawa lain yang aktif pada pH netral (Georgievaa et al., 2015). L. fermentum galur ME-3 selain memiliki aktivitas antimikroba juga memiliki aktivitas antioksidatif (Mikelsaar dan Zilmer, 2009).

Tabel 1. Hasil identifikasi beberapa isolat BAL asal tape yang berpotensi sebagai kandidat probiotik

\begin{tabular}{lcccc}
\hline \multicolumn{1}{c}{ Asal Isolat } & $\begin{array}{c}\text { Kode } \\
\text { Isolat }\end{array}$ & Morfologi & $\begin{array}{c}\text { Hasil Identifikasi API50 CHL } \\
\text { (Spesies) }\end{array}$ & $\begin{array}{c}\text { Kesamaan dengan Kultur } \\
\text { Referensi (\%) }\end{array}$ \\
\hline Tape ketan & BK2-5 & Batang & Lactobacillus fermentum 1 & 97 \\
Tape ketan & BK2-7 & Batang & Lactobacillus fermentum 2 & 85,4 \\
Tape singkong & NG6-3 & Kokus & Pediococcus acidilactici & 85,4 \\
Tape singkong & NG6-4 & Kokus & Pediococcus acidilactici & 98,8 \\
Tape singkong & SH6-8 & Batang & Lactobacillus plantarum 1 & 99,9 \\
Tape singkong & TS4-5 & Batang & Lactobacillus fermentum 2 & 91,3 \\
\hline
\end{tabular}

Tabel 2. Aktivitas antimikroba isolat BAL asal tempe dan tape terhadap bakteri patogen

\begin{tabular}{|c|c|c|c|c|c|}
\hline \multirow[b]{2}{*}{ Isolat BAL } & \multicolumn{5}{|c|}{ Zona Hambat (mm) } \\
\hline & $\begin{array}{c}\text { E. coli ATCC } \\
25922\end{array}$ & $\begin{array}{l}\text { S. typhimurium } \\
\text { ATCC } 14028\end{array}$ & $\begin{array}{l}\text { L. monocytogenes } \\
\text { ATCC } 7644\end{array}$ & $\begin{array}{c}\text { S. aureus } \\
\text { ATCC } 25923\end{array}$ & $\begin{array}{c}\text { B. cereus } \\
\text { ATCC } 11778\end{array}$ \\
\hline L. plantarum 2 W22409 & $15,1 \pm 0,66$ & $13,9 \pm 0,43^{e}$ & $17,7 \pm 0,65^{\text {ae }}$ & $15,6 \pm 0,60^{e}$ & $17,0 \pm 0,44$ \\
\hline $\begin{array}{l}\text { P. pentosaceus } 1 \\
\text { W2SR04 }\end{array}$ & $12,0 \pm 0,21^{\mathrm{cd}}$ & $11,5 \pm 0,64^{b c}$ & $17,2 \pm 0,16^{\text {cde }}$ & $13,6 \pm 0,71^{c}$ & $14,8 \pm 0,45^{d}$ \\
\hline $\begin{array}{l}\text { P. pentosaceus } 2 \\
\text { W2SR05 }\end{array}$ & $12,2 \pm 0,41^{\mathrm{e}}$ & $13,0 \pm 0,41^{d}$ & $16,8 \pm 0,63^{\mathrm{cd}}$ & $16,5 \pm 0,70^{f}$ & $16,3 \pm 0,15^{\mathrm{e}}$ \\
\hline $\begin{array}{l}\text { L. delbrueckii W24802 } \\
\text { W. confusa S2SR08 }\end{array}$ & $\begin{array}{l}11,4 \pm 0,56^{\mathrm{a}} \\
110+024^{\mathrm{a}}\end{array}$ & $\begin{array}{l}12,0 \pm 0,33^{\mathrm{c}} \\
120+0,63^{\mathrm{c}}\end{array}$ & $\begin{array}{l}12,6 \pm 0,46^{a} \\
127+047^{a}\end{array}$ & $10,6 \pm 0,50^{\mathrm{a}}$ & $11,8 \pm 0,75^{\mathrm{D}}$ \\
\hline L. fermentum S21209 & $12,4 \pm 0,08^{\mathrm{T}}$ & $13,7 \pm 0,23^{\mathrm{e}}$ & $19,7 \pm 0,04$ & $16,3 \pm 0,04^{\mathrm{T}}$ & $15,1 \pm 0,19^{a}$ \\
\hline L. fermentum 1 BK2-5 & $9,6 \pm 0,43^{\mathrm{a}}$ & $10,6 \pm 0,43^{a}$ & $17,2 \pm 0,55^{\text {cae }}$ & $11,0 \pm 0,04^{\mathrm{a}}$ & $16,7 \pm 0,60^{\text {ет }}$ \\
\hline L. fermentum $2 \mathrm{BK} 2-7$ & $11,1 \pm 0,43^{\mathrm{c}}$ & $10,9 \pm 0,35^{\text {ао }}$ & $18,4 \pm 0,76^{\mathrm{e}}$ & $14,6 \pm 0,49^{a}$ & $12,4 \pm 0,12^{\mathrm{c}}$ \\
\hline L. fermentum 2 TS4-5 & $10,8 \pm 0,43^{a}$ & $11,8 \pm 0,82^{\mathrm{C}}$ & $12,0 \pm 0,15^{\mathrm{a}}$ & $11,0 \pm 0,05^{\mathrm{a}}$ & $10,5 \pm 0,70^{a}$ \\
\hline L. plantarum $1 \mathrm{SH} 6-8$ & $11,5 \pm 0,55^{\mathrm{ca}}$ & $11,4 \pm 0,45^{\mathrm{DC}}$ & $16,1 \pm 0,67^{\mathrm{C}}$ & $11,7 \pm 0,67^{\mathrm{D}}$ & $12,0 \pm 0,41^{\mathrm{DC}}$ \\
\hline P. acidilactici NG6-3 & $11,2 \pm 1,15^{\mathrm{D}}$ & $10,5 \pm 0,58^{a}$ & $14,8 \pm 0,70^{\circ}$ & $11,2 \pm 0,16^{\text {ad }}$ & $12,1 \pm 0,72^{\mathrm{DC}}$ \\
\hline P. acidilactici NG6-4 & $12,2 \pm 0,41^{\mathrm{ca}}$ & $11,6 \pm 0,77^{\mathrm{C}}$ & $18,4 \pm 1,02^{\mathrm{e}}$ & $13,8 \pm 0,55^{\mathrm{c}}$ & $17,6 \pm 0,42^{g}$ \\
\hline
\end{tabular}




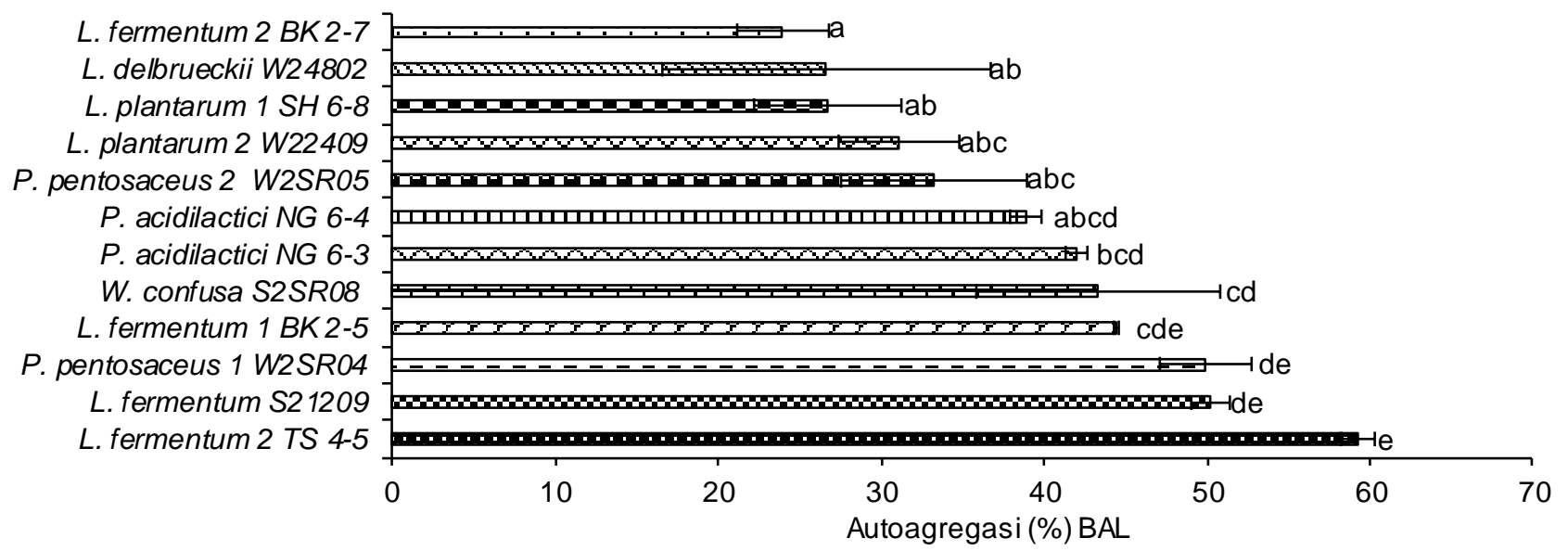

Gambar 2. Kemampuan autoagregasi (\%) isolat BAL asal tempe dan tape

\section{Sifat hidrofobisitas BAL asal tempe dan tape}

Sifat hidrofobisitas suatu bakteri memengaruhi kemampuan autoagregrasi dan penempelan bakteri terhadap berbagai permukaan. Sifat hidrofobisitas permukaan sel BAL ditunjukkan dengan adhesinya atau afinitasnya terhadap xilena (Kos et al., 2003). Walaupun hasil pengujian hidrofobisitas dan agregasi tidak selalu berkorelasi dengan penempelan bakteri secara in vivo, namun pengujian hidrofobisitas bermanfaat untuk mengetahui sifat permukaan sel bakteri yang penting untuk penempelan. Kemampuan agregasi dan hidrofobisitas bukan satu-satunya komponen yang bertanggung jawab terhadap penempelan karena mekanisme penempelan merupakan proses yang kompleks (Garcia-Cayuela et al., 2014). Berdasarkan afinitas terhadap pelarut xilena (Tabel 3), L. fermentum 1 BK2-5 memiliki sifat hidrofobisitas yang paling kuat dan berbeda nyata dengan isolat lainnya. Afinitas terhadap xilena yang cukup tinggi ditunjukkan oleh L. fermentum S21209 dan L. fermentum 2 TS4-5. Afinitas terhadap hidrokarbon di atas $50 \%$ dinyatakan sebagai hidrofobik kuat dan antara $20-30 \%$ dinyatakan moderat, sedangkan di bawah $20 \%$ dinyatakan sebagai negatif (Santos et al., 1990).

Isolat yang lainnya memiliki afinitas yang rendah terhadap xilena yang menunjukkan permukaan yang lebih hidrofilik. Sifat hidrofobisitas ini berkaitan dengan keberadaan komponen dinding sel seperti fosfolipid, polisakarida dan komponen luar pada permukaan sel bakteri (Kos et al., 2003). Komponen dinding sel bakteri mempunyai fungsi penempelan pada sel inang yang membentuk interaksi hidrofobik. Protein pada permukaan sel dan asam lipoteikoat menghasilkan sifat hidrofobik, sedangkan polisakarida menghasilkan sifat hidrofilik (Garcia-Cayuela et al., 2014). Bakteri bersifat hidrofobik karena permukaan selnya bermuatan negatif. Hidrofobisitas permukaan sel biasanya berasosiasi dengan sifat penempelan bakteri, namun bervariasi tergantung dari galur bakteri dan dipengaruhi oleh medium partumbuhan, umur bakteri dan struktur permukaan sel bakteri. Penelitian yang dilakukan oleh Nuraida et al. (2012) terhadap 8 isolat Lactobacillus asal air susu ibu (ASI) menunjukkan semua isolat bersifat hidrofilik, yang berbeda dengan hasil penelitian ini.

Afinitas terhadap kloroform, pelarut yang bersifat asam, menunjukkan permukaan sel bersifat sebagai penerima elektron dan afinitas terhadap etil asetat, pelarut bersifat basa, menunjukkan permukaan sel sebagai donor elektron (Kos et al., 2003). Sebagian isolat menunjukkan afinitas yang lebih tinggi terhadap kloroform dibandingkan terhadap etil asetat (Tabel 3).

\section{Sifat autoagregasi BAL asal tempe dan tape}

Agregasi, yang terdiri dari autoagregasi dan koagregasi, merupakan proses reversible akumulasi sel bakteri. Autoagregasi merupakan kemampuan bakteri untuk menempel dengan sesamanya, sedangkan koaggregasi merupakan kemampuan bakteri untuk membentuk agregat dengan bakteri lain yang berbeda (Janković et al., 2012). Sifat autoagregasi galur probiotik penting untuk menempel pada sel epitel usus, sedangkan kemampuan melakukan koagregasi penting dalam peranan probiotik sebagai penghalang yang menghambat kolonisasi bakteri patogen pada saluran pencernaan (Kos et al., 2003). Kemampuan autoagregasi suatu probiotik merupakan prasyarat untuk dapat berkolonisasi dan bertahan pada saluran pencernaan (Janković et al., 2012).

Semua isolat BAL asal tempe dan tape menunjukkan kemampuan autoagregasi di atas $10 \%$, tujuh isolat BAL memiliki kemampuan autoagregasi di atas 40\% (Gambar 3). Menurut Del Re et al. (2000), bakteri dengan kemampuan autoagregasi di bawah $10 \%$ dinyatakan sebagai nonautoagregasi. Gambar 3 menunjukkan isolat L. fermentum TS4-5, L. fermentum S21209, L. Fermentum 1 BK2-5 dan $P$. pentosaceus 1 W2SR04 memiliki kemampuan autoagregasi paling tinggi, yang berbeda dengan isolat BAL lainya. Setiap isolat BAL memiliki kemampuan autoagregasi berbeda-beda. 
Tabel 3. Adhesi (\%) isolat BAL asal tempe dan tape ke berbagai pelarut

\begin{tabular}{|c|c|c|c|}
\hline \multirow{2}{*}{ Isolat BAL } & \multicolumn{3}{|c|}{ Adhesi (\%) } \\
\hline & Xilena & Kloroform & Etil asetat \\
\hline L. fermentum 1 BK 2-5 & $64,84 \pm 3,17^{e}$ & $77,11 \pm 3,54$ & $76,01 \pm 2,20^{9}$ \\
\hline L. fermentum 2 BK 2-7 & $3,40 \pm 5,50$ a & $10,88 \pm 5,47^{\mathrm{Dcd}}$ & $16,23 \pm 1,33^{\circ}$ \\
\hline L. fermentum 2 TS 4-5 & $38,97 \pm 0,67^{\mathrm{a}}$ & $17,69 \pm 2,13^{\text {cae }}$ & $13,89 \pm 2,22^{\circ}$ \\
\hline L. plantarum $1 \mathrm{SH} 6-8$ & $12,79 \pm 4,80^{\mathrm{D}}$ & $19,44 \pm 3,81^{\text {aer }}$ & $8,05 \pm 2,82^{a}$ \\
\hline P. acidilactici NG 6-3 & $1,66 \pm 1,85^{\mathrm{a}}$ & $5,66 \pm 6,06^{\text {ao }}$ & $5,56 \pm 2,50^{\mathrm{a}}$ \\
\hline$P$. acidilactici NG 6-4 & $7,35 \pm 3,70^{\text {ad }}$ & $20,55 \pm 4,40^{\mathrm{er}}$ & $19,44 \pm 3,80^{a}$ \\
\hline L. plantarum 2 W22409 & $28,83 \pm 8,63^{c}$ & $49,46 \pm 4,66^{9}$ & $43,69 \pm 2,95^{\text {ar }}$ \\
\hline P. pentosaceus 1 W2SR04 & $12,09 \pm 0,71^{\mathrm{D}}$ & $9,41 \pm 1,45^{\mathrm{adc}}$ & $7,26 \pm 1,44^{\mathrm{a}}$ \\
\hline P. pentosaceus 2 W2SR05 & $28,72 \pm 7,35^{\mathrm{c}}$ & $66,06 \pm 3,98^{n}$ & $48,85 \pm 4,27^{\top}$ \\
\hline L. delbrueckii W24802 & $23,18 \pm 0,28^{\mathrm{C}}$ & $26,51 \pm 0,64^{\prime}$ & $29,01 \pm 0,12^{\mathrm{C}}$ \\
\hline W. confusa S2SR 08 & $12,42 \pm 2,73^{\mathrm{D}}$ & $1,47 \pm 3,43^{\mathrm{a}}$ & $3,32 \pm 4,13^{a}$ \\
\hline L. fermentum S21209 & $42,71 \pm 0,73^{a}$ & $51 \pm 0,88^{9}$ & $42,71 \pm 1,86^{a}$ \\
\hline
\end{tabular}

Menurut Garcia-Cayuela et al. (2014), agregasi selular tergantung pada spesies dan lingkungan. Agregat dapat menempel pada permukaan mukosa sehingga bakteri probiotik dapat bertahan pada usus (Garcia-Cayuela et al., 2014). Agregat juga akan mempersulit bakteri patogen untuk menempel pada permukaan usus sehingga bakteri patogen mudah dikeluarkan dari saluran pencernaan. Mekanisme agregasi selular merupakan interaksi kompleks antara komponen permukaan sel dan faktor-faktor yang disekresikan (Garcia-Cayuela et al., 2014). Faktor-faktor seperti protein, glikoprotein, asam teikoat dan asam lipoteikoat pada permukaan dinding sel bakteri memengaruhi kemampuan penempelan, autoagregasi dan hidrofobisitas (Ramiah et al., 2008). Namun demikian, mekanisme senyawasenyawa tersebut dalam memengaruhi kemampuan penempelan, autoagregasi dan hidrofobisitas belum digambarkan secara jelas. Sifat autoagregasi suatu bakteri dapat dipengaruhi oleh sifat hidrofobisitas permukaan sel (Kos et al., 2003). Ketiga isolat yang memiliki hidrofobisitas tinggi menunjukkan kemampuan autoagregasi yang tinggi, namun $P$. pentosaceus W2SR04 dan $P$. acidilactici yang menunjukkan kemampuan autoagregasi cukup tinggi tidak bersifat hidrofobik. Hasil yang sama juga diamati oleh Garcia-Cayuela et al. (2014) pada L. plantarum yang kemampuan autoagregasinya tidak berkorelasi dengan sifat hidrofobisitasnya.

\section{Sifat koagregasi BAL asal tempe dan tape}

Kemampuan koagregasi suatu bakteri probiotik berkorelasi dengan kemampuannya dalam membentuk barrier yang dapat mencegah kolonisasi bakteri patogen pada saluran pencernaan (GarciaCayuela et al., 2014). Oleh karena itu, BAL yang mampu berkoagregasi dengan bakteri patogen merupakan sifat yang menguntungkan dalam perannya sebagai probiotik (Campana et al., 2017). Pada penelitian ini pengujian koagregasi dilakukan antara isolat BAL dan lima bakteri patogen.

Hasil pengujian koagregasi pada Tabel 4 menunjukkan bahwa isolat $L$. fermentum S21209 memi- liki kemampuan koagregasi paling tinggi dengan kelima bakteri patogen. Hasil pengujian koagregasi ini sesuai dengan hasil uji autoagregasi dan berkorelasi dengan aktivitas antimikroba, dimana $L$. fermentum S21209 memiliki sifat antimikroba yang lebih kuat dibandingkan BAL lainnya terhadap semua patogen uji. Kemampuan koagregasi sangat dipengaruhi oleh spesies dan galur yang berbeda (Bao et al., 2010). Dari 11 galur $L$. fermentum, hanya dua galur yang mempunyai nilai koagregasi yang tinggi (>30\%). Sementara, hasil penelitian ini hanya $L$. fermentum S21209 yang memiliki nilai koagregasi 24,83$35,82 \%$, yang lainnya jauh di bawah $30 \%$. Pengujian koagregasi merupakan metode yang baik untuk mengevaluasi interaksi antara BAL dan bakteri patogen. BAL yang berkoagregasi dengan patogen dapat memaparkan senyawa antimikrobanya secara langsung terhadap bakteri patogen (Jankovic et al., 2012), sehingga BAL dapat mengendalikan patogen disekitarnya (Kaewnopparat et al., 2013). Selain menghasilkan senyawa antimikroba, mekanisme penghambatan kolonisasi patogen pada saluran pencernaan adalah melalui mekanisme koagregasi (Campana et al., 2017).

\section{KESIMPULAN}

Isolat $P$. acidilactici NG6-4, L. fermentum BK2-5 dan $L$. fermentum BK2-7 asal tape memiliki ketahanan yang baik terhadap $\mathrm{pH}$ 2,0 dan garam empedu. L. fermentum S21209 memiliki sifat antimikroba yang kuat terhadap semua patogen. $L$. fermentum 1 BK 2-5 memiliki sifat hidrofobisitas tertinggi, diikuti oleh L. fermentum S21209 dan L. fermentum TS4-5. L. fermentum S21209 asal tempe dan L. fermentum TS 4-5, L. fermentum 1 BK2-5, P. pentosaceus 1 WSR04 asal tape memiliki kemampuan autoagregasi tertinggi diantara isolat BAL asal tempe dan tape. Sifat hidrofobisitas $L$. fermentum asal tempe dan tape berkorelasi dengan sifat autoagregasinya. 
Tabel 4. Kemampuan koagregasi (\%) isolat BAL asal tempe dan tape terhadap lima bakteri patogen

\begin{tabular}{lccccc}
\hline \multirow{2}{*}{ Isolat BAL } & \multicolumn{5}{c}{ Koaggregasi (\%) } \\
\cline { 2 - 6 } & $\begin{array}{c}\text { E. coli ATCC } \\
25922\end{array}$ & $\begin{array}{c}\text { S. typhimurium } \\
\text { ATCC } 14028\end{array}$ & $\begin{array}{c}\text { L. monocytogenes } \\
\text { ATCC } 7644\end{array}$ & $\begin{array}{c}\text { S. aureus ATCC } \\
25923\end{array}$ & $\begin{array}{c}\text { B. cereus } \\
\text { ATCC } 11778\end{array}$ \\
\hline L. fermentum 1 BK2-5 & $19,00 \pm 0,12^{\mathrm{bc}}$ & $8,60 \pm 5,64^{\mathrm{bc}}$ & $6,00 \pm 0,72^{\mathrm{cd}}$ & $22,08 \pm 1,17^{\mathrm{ef}}$ & $18,72 \pm 0,61^{\mathrm{e}}$ \\
L. fermentum 2 BK2-7 & $2,86 \pm 1,29^{\mathrm{abc}}$ & $4,84 \pm 0,92^{\mathrm{abc}}$ & $5,16 \pm 0,73^{\mathrm{bcd}}$ & $25,46 \pm 2,11^{\mathrm{e}}$ & $17,84 \pm 0,67^{\mathrm{de}}$ \\
L. fermentum 2 TS4-5 & $18,44 \pm 3,25^{\mathrm{c}}$ & $1,74 \pm 0,10^{\mathrm{a}}$ & $7,89 \pm 1,23^{\mathrm{d}}$ & $19,70 \pm 1,11^{\mathrm{cde}}$ & $16,96 \pm 1,51^{\mathrm{de}}$ \\
L. plantarum 1 SH6-8 & $6,06 \pm 0,06^{\mathrm{ab}}$ & $1,20 \pm 0,03^{\mathrm{a}}$ & $2,85 \pm 1,30^{\mathrm{c}}$ & $16,36 \pm 0,29^{\mathrm{c}}$ & $4,15 \pm 0,76^{\mathrm{a}}$ \\
P. acidilactici NG6-3 & $0,45 \pm 0,16^{\mathrm{ab}}$ & $2,25 \pm 0,71^{\mathrm{ab}}$ & $4,42 \pm 0,77^{\mathrm{abcd}}$ & $33,05 \pm 0,20^{\mathrm{a}}$ & $10,36 \pm 1,54^{\mathrm{bc}}$ \\
P. acidilactici NG6-4 & $2,45 \pm 0,52^{\mathrm{ab}}$ & $1,25+0,47^{\mathrm{a}}$ & $1,22 \pm 0,27^{\mathrm{a}}$ & $17,83 \pm 0,48^{\mathrm{cd}}$ & $3,95 \pm 0,26^{\mathrm{a}}$ \\
L. plantarum 2 W22409 & $1,62 \pm 0,00^{\mathrm{ab}}$ & $1,51 \pm 1,36^{\mathrm{a}}$ & $2,98 \pm 0,11^{\mathrm{abc}}$ & $3,71 \pm 0,31^{\mathrm{e}}$ & $1,49 \pm 0,53^{\mathrm{a}}$ \\
P. pentosaceus 1 & $7,31 \pm 2,74^{\mathrm{abc}}$ & $3,51 \pm 0,11^{\mathrm{abc}}$ & $12,39 \pm 2,56^{\mathrm{e}}$ & $3,07 \pm 1,39^{\mathrm{ab}}$ & $8,31 \pm 1,17^{\mathrm{b}}$ \\
W2SR04 & & & & \\
P. pentosaceus 2 & $2,90 \pm 0,64^{\mathrm{abc}}$ & $4,93 \pm 0,00^{\mathrm{abc}}$ & $8,10 \pm 0,11^{\mathrm{d}}$ & $10,45 \pm 0,45^{\mathrm{b}}$ & $13,01 \pm 1,74^{\mathrm{e}}$ \\
W2SR05 & & & & \\
L. delbrueckii W24802 & $5,69 \pm 2,72^{\mathrm{c}}$ & $9,34 \pm 1,05^{\mathrm{c}}$ & $5,77 \pm 0,22^{\mathrm{bcd}}$ & $21,16 \pm 1,27^{\mathrm{de}}$ & $12,68 \pm 1,90^{\mathrm{c}}$ \\
W. confusa S2SR08 & $7,76 \pm 4,26^{\mathrm{c}}$ & $9,00 \pm 2,57^{\mathrm{c}}$ & $2,22 \pm 1,57^{\mathrm{ab}}$ & $22,51 \pm 0,43^{\mathrm{ef}}$ & $14,51 \pm 1,51^{\mathrm{cd}}$ \\
L. fermentum S21209 & $29,85 \pm 1,04^{\mathrm{d}}$ & $32,72 \pm 0,65^{\mathrm{d}}$ & $24,83 \pm 0,65^{\mathrm{f}}$ & $35,82 \pm 0,61^{\mathrm{f}}$ & $30,72 \pm 0,37^{\dagger}$ \\
\hline
\end{tabular}

Kemampuan koagregasi L. fermentum S21209 dengan bakteri patogen berkorelasi dengan kemampuan autoagregasi dan aktivitas antimikroba. Berdasarkan kemampuan untuk bertahan pada kondisi asam, garam empedu, autoagregasi dan aktivitas antimikroba, L. fermentum S212 09 asal tempe dan L. fermentum BK2-5 asal tape ketan merupakan BAL yang paling berpotensi sebagai kandidat probiotik. Mekanisme agregasi dan korelasinya terhadap sifat penempelan dan kemampuan bertahan pada saluran pencernaan untuk kedua BAL ini perlu diteliti lebih lanjut untuk mendukung pemanfaatannya sebagai probiotik.

\section{UCAPAN TERIMAKASIH}

Sebagian penelitian ini didanai oleh Kementerian Riset, Teknologi, dan Pendidikan Tinggi melalui Skema Penelitian Berbasis Kompetensi.

\section{DAFTAR PUSTAKA}

Antara NS, Dibia IN, Aryanta WR. 2009. Characterization of lactic acid bacteria isolated from horse milk of Bima. Agritech 29: 1-9.

Arief II, Jenie BSL, Astawan M, Witarto BA. 2010. Efektivitas probiotik Lactobacillus plantarum 2C12 dan Lactobacillus acidhopillus 2B4 sebagai pencegah diare pada tikus percobaan. Media Peternakan 33: 137-143. DOI: 10.5398/med pet.2010.33.3.137.

Bao Y, Zhang Y, Zhang Y, Liu Y, Shuiquan W, Dong S, Wang $Y$, Zhang $H$. 2010. Screening of potential probiotic properties of Lactobacillus fermentum isolated from traditional dairy products. Food Control 21: 695-701. DOI: 10.1016/j.food cont.2009.10.010.
Blaabjerg S, Artzi DM, Aabenhus R. 2017. Probiotics for the prevention of antibiotic-associated diarrhea in outpatients-a systematic review and meta-analysis. Antibiotics 6: 1-17. DOI: 10.339 0/antibiotics6040021.

Campana R, Saskia Van H, Wally B. 2017. Strainspecific probiotic properties of lactic acid bacteria and their interference with human intestinal pathogens invasion. Gut Pathog 9: 1-12. DOI: 10.1186/s13099-017-0162-4.

Choi EA, Chang CH. 2015. Cholesterol-lowering effects of a puntative probiotic strain Lactobacillus plantarum EM isolated from kimchi. LWTFood Sci Tech 62: 210-217. DOI: 10.1016/j.Iwt. 2015.01.019.

Chávarri M, Marañón I, Villarán MC. 2012. Encapsulation technology to protect probiotic bacteria. Intech 23: 501-540. DOI: 10.5772/50046.

Del Re B, Sgorbati B, Miglioti M, Palenzona D. 2000. Adhesion autoaggregation and hydrofobicity of 13 strains of Bifidobacterium longum. Lett Appl Microbiol 31: 348-442. DOI: 10.1046/j.1365-267 2.2000.00845.x.

Efriwati, Suwanto A, Rahayu G, Nuraida L. 2013. Population dynamics of yeast and lactic acid bacteria (LAB) during tempeh production. Hayati J Biosci 20: 57-64. DOI: 10.4308/hjb.20. 2.57 .

Emmawati A. 2015. Kajian Antiinfeksi Isolat Bakteri Asam Laktat Asal Mandai. [Disertasi]. Bogor: Fakultas Teknologi Pertanian, Institut Pertanian Bogor.

FAO/WHO. 2002. Guidelines for the evaluation of probiotics in food. Report of Joint FAO/WHO Working Group on drafting Guidelines for the evaluation of probiotics in food. 1-11. London Ontario, Canada. 
Ganjbakhsh SE, Rezaee P. 2017. The Effect of probiotics on immune system. J Bacteriol Mycol 5: 319-320. DOI: 10.15406/jbmoa.2017.05.00139.

Garcia-Cayuela T, Korany AM, Bustos I, de Cadiñanos LPG, Requena T, Peláez C. 2014. Adhesion abilities of dairy Lactobacillus plantarum strains showing an aggregation phenotype. Food Res Int 57: 44-50. DOI: 10.1016/j.foodres. 2014.01.010.

Georgieva R, Yocheva L, Tserovska L, Zhelezova G, Stefanova N, Atanasova A, Danguleva A, Ivanova G, Karapetkov N, Rumyan N, Karaivanova E. 2015. Antimicrobial activity and antibiotic susceptibility of Lactobacillus and Bifidobacterium spp. intended for use as starter and probiotic cultures. Biotechnol Biotec Eq 29: 8491. DOI: $10.1080 / 13102818.2014 .987450$.

Janković T, Frece J, Abram M, Gobin I. 2012. Aggregation ability of potential probiotic Lactobacillus plantarum strains. Int $\mathrm{J}$ Sanitary Eng Res 6: $19-24$.

Kaewnopparat S, Dangmanee N, Kaewnopparat N, Srichana T, Chulasiri M, Settharaksa S. 2013. In vitro probiotic properties of Lactobacillus fermentum SK5 isolated from vagina of a healthy woman. Anaerobe 22: 6-13. DOI: 10.1016/j.an aerobe.2013.04.009.

Kinová SH, Bilková A, Bukovský M. 2008. Lactobacilli and their probiotic properties. Čes Slov Farm 57: 95-98.

Kos B, Šušković J, Vuković S, Šimpraga M, Frece J, Matošić S. 2003. Adhesion and aggregation ability of probiotic strain Lactobacillus acidophiIus M92. J Appl Microbiol 94: 981-987. DOI: 10. 1046/j.1365-2672.2003.01915.x.

Kumar KS, Sastry N, Polaki H, Mishra. 2015. Colon cancer prevention through probiotics: An overview. J Cancer Sci Ther 7: 81-92. DOI: 10.417 2/1948-5956.1000329.

Mikelsaar M, Zilmer M. 2009. Lactobacillus fermentum ME-3 an antimicrobial and antioxidative probiotic. J Microb Ecol Health D 21: 1-27. DOI: 10.1080/08910600902815561.

Nuraida L, Winarti S, Hana, Prangdimurti E. 2011. Evaluasi in vitro terhadap kemampuan isolat bakteri asam laktat asal air susu ibu untuk mengasimilasi kolesterol dan mendekonjugasi garam empedu. J Teknol Industri Pangan 22: 46-52.
Nuraida L, Anggraeni D, Hariyadi-Dewanti R. 2012. Adherence properties of lactic acid bacteria as probiotic candidates isolated from breast milk. Asian J Food Agr Ind 5: 500-511.

Nuraida L, Owens JD. 2014. Sweet, sour, alchoholic solid substate fungal fermentation. Di dalam: Indigenous Fermented Food of southeast Asia. Owens JD, editor. Fermented Food and Beverages Series. 137-155. Boca Raton (US), CRC Press.

Nuraida L. 2015. A review: Health promoting lactic acid bacteria in traditional Indonesian fermented foods. Food Sci Hum Wellness 4: 47-55. DOI: 10.1016/j.fshw.2015.06.001.

Nurdini AL, Nuraida L. Suwanto A Suliantari. 2015. Mycrobial growth dynamics during tempe fermentation in two different home industries. Int Food Res J 22: 1668-1674.

Pan X, Chen F, Wua T, Tang H, Zhao Z. 2009. The acid, bile tolerance and antimicrobial property of Lactobacillus acidophilus NIT. Food Control 20: 598-602. DOI: 10.1016/j.foodcont.2008.08.019.

Pan DD, Zeng QX, Yan YT. 2011. Characterisation of Lactobacillus fermentum SM-7 isolated from koumiss, a potential probiotic bacterium with cholesterol-lowering effects. J Sci Food Agr 9: 512-518. DOI: 10.1002/jsfa.4214.

Pato U, Surono IS, Koesnandar, Hosono A. 2004. Hypocholesterolemic effect of indigenous dadih lactic acid bacteria by deconjugation of bile salts. Asian-Australas J Anim Sci 17: 17411745. DOI: 10.5713/ajas.2004.1741.

Patrick OM. 2012. Lactic acid bacteria in health and disease. Rwanda J Health Sci 1: 39-50.

Ramiah K, van Reenen CA, Dicks LMT. 2008. Surface-bound proteins of Lactobacillus plantarum 423 that contribute to adhesion of Caco-2 cells and their role in competitive exclusion and displacement of Clostridium sporogenes and Enterococcus faecalis. Res Microbiol 159: 470475. DOI: 10.1016/j.resmic.2008.06.002.

Ratihwulan H. 2016. Karakteristik Sensori Tape Ketan dan Tape Singkong Dari Industri Rumah Tangga yang Berbeda Di Bogor. [Skripsi]. Bogor: Fakultas Teknologi Pertanian, Institut Pertanian Bogor. 
Reis JA, Paula AT, Casarotti SN, Penna ALB. 2012. Lactic acid bacteria antimicrobial compounds: Characteristics and applications. Food Eng Rev 4: 124-140. DOI: 10.1007/s12393-012-9051-2.

Samaržija D, Tudor M, Prtilo T, Špehar ID, Zamberlin S, Havranek J. 2009. Probiotic bacteria in prevention and treatment of diarrhea. Mljekarstvo 59: 28-32.

Santos Y, Bandin I, Nicto TP, Bruno DW, Ellis AE, Taranzo AT. 1990. Proposed criteria of hydrophobicity. J Letters In Appl Microbiol 13: 343346.

Sivieri K, Bedani R, Cavallini DCU, Rossi EA. 2013. Probiotics and intestinal microbiota: implication in colon cancer prevention. In Tech 9: 217-242. DOI: $10.5772 / 51696$.
Todorov SD, Vaz-Velho M, de Melo Franco BDG, Holzapfel WH. 2013. Partial characterization of bacteriocins produced by three strains of Lactobacillus sakei, isolated from salpicao, a fermented meat product from North-West of Portugal. Food Control 30: 111-121. DOI: 10.1016/j. foodcont.2012.07.022.

Touw KS. 2014. Identifikasi Bakteri Asam Laktat Dominan Selama Fermentasi Tempe dan Evaluasi Potensinya Sebagai Probiotik. [Skripsi]. Bogor: Fakultas Teknologi Pertanian, Institut Pertanian Bogor.

Vonk RJ, Reckman GAR, Harmsen HJM, Priebe MG. 2012. Probiotics and lactose intolerance. Intech 7: 149-160. DOI: 10.5772/51424. 